\title{
Guillain-Barré syndrome in children

\author{
Clinic, laboratorial and epidemiologic \\ study of 61 patients
}

\author{
Vanessa van der Linden', José Albino da Paz², \\ Erasmo Barbante Casella², Maria Joaquina Marques-Dias ${ }^{2,3}$
}

\begin{abstract}
The aim of the study was to analyze the epidemiologic, clinical, laboratory and development profile of Guillain-Barré syndrome series studied at the Child Institute, between 1989 and 2000. From the 61 patients that fulfilled the selection criteria, aged between 7 months and 13 years old, no sexual or seasonal variation was observed. Clinical events prior to neurological symptoms (with an average time gap of 20.7 days) were observed in $62.3 \%$, $55 \%$ had cranial nerve disturbances, $27.9 \%$ dysautonomic symptoms, and $27.9 \%$ respiratory dysfunction. Installation time varied from 2-40 days, plateau from 0-28 days and recuperation from $30-480$ days; $94 \%$ of patients had a complete clinical recuperation. Electrophysiology in 20 patients disclosed an abnormal demyelination pattern in 15 , an exclusively motor axonal pattern in 4 and a mixed pattern in 1 patient. The results obtained did not differ from those in the literature but it was observed that boys and older children had a longer recuperation time. It was not possible to correlate electroneurography with clinical abnormalities and evolution due to the reduced number of patients.
\end{abstract}

Key words: Guillain-Barré syndrome, poliradiculoneuropathy.

\section{Síndrome de Guillain-Barré em crianças: estudo clínico, laboratorial e epidemiologico em 61 pacientes}

\section{RESUMO}

O objetivo do estudo foi analisar retrospectivamente, quanto ao perfil clínico, laboratorial, epidemiológico e evolutivo a casuística da síndrome de Guillain-Barré no Instituto da Criança, entre 1989 e 2000. Preencheram os critérios de seleção 61 pacientes, com idades entre 7 meses e 13 anos, e não se observou variação entre sexos nem sazonal. Em 62,3\% houve uma afecção precedendo o quadro neurológico, num tempo médio de 20,7 dias; $55 \%$ apresentaram acometimento de nervos cranianos, 27,9\% distúrbios disautonômicos e 27,9\% comprometimento respiratório. A fase de progressão variou de 2 a 40 dias, a de platô de 0 a 28 dias e a de recuperação de 30 a 480 dias e $94 \%$ tiveram recuperação total. A eletroneurografia, em 20 pacientes, mostrou padrão desmielinizante em 15, padrão axonal puramente motor em 4 e padrão misto em 1 . Os resultados não diferiram dos encontrados na literatura, mas os meninos e os pacientes na faixa etária superior apresentaram maior tempo de recuperação total. Não foi possível estabelecer relação entre resultados da ENMG e o quadro clínico e evolutivo em vista do pequeno numero de pacientes com esse exame. Palavras-chave: síndrome de Guillain-Barré, poliradiculoneuropatia.

\section{Correspondence}

Maria Joaquina Marques-Dias

Av. Dr. Eneas de Carvalho de Aguiar 647

05403-900 São Paulo SP - Brasil

E-mail: majomadi@usp.br

Received 6 June 2009

Received in final form 17 September 2009

Accepted 27 October 2009
The Guillain-Barré syndrome (GBS) is an autoimmune poliradiculoneuropathy, clinically characterized by the presence of flaccid paralysis and areflexia, variable sensitive involvement and increase in total protein in cerebrospinal fluid (CSF).

It is the most frequent cause of acute or sub acute flaccid paralysis, mainly after 
poliomyelitis eradication ${ }^{1}$. The syndrome was initially described by Landry in 1859 as an acute increasing paralysis'; Barre and Strohl in 1916 related a benign acute polyneuritis with increase in protein levels without pleocytosis (albumin-cytological dissociation) ${ }^{3}$. It can occur at any age, in a sporadic way, and can be preceded by an acute infectious disease (two-thirds of cases) $)^{4-6}$. Recuperation is usually complete, but 5 to $25 \%$ of cases can remain with motor sequelae ${ }^{7}$. A fatal course has been registered in 2 to $3 \%$ of the cases, in association with dysautonomic and respiratory complications ${ }^{8}$.

This study analyzes a GBS series studied between 1989-2000, with the purpose of defining its epidemiological, clinical, laboratorial and follow-up profile.

\section{METHOD}

This series of patients with Guillain-Barré syndrome were retrospectively studied and prospectively evaluated at the Child Institute of Clinical Hospital of School of Medicine, University of São Paulo (ICr-HCFMUSP) between January 1989 and February 2000. The ICr is a third level pediatric hospital that receive patients from the city and the state of São Paulo as also from the other parts of the country and even from other countries of Latin America.

The case search was made consulting ICr-HCFMUSP's and Child Neurology Unit using the key words GuillainBarré syndrome, poliradiculoneuropathy, peripheral neuropathy. The medical records were recovered by the Medical Files and Statistics Service of the Child Institute and the information was collected to conform to a pre-established protocol.

Cases were included when they fulfilled the clinical and CSF classical definition of Guillain-Barré syndrome.

CSF samples were collected by lumbar puncture and analyzed in HCFMUSP's Central Laboratory according to Spina-França methods?.

The electrophysiology was performed at the Neurophysiology Section of HCFMUSP with a digital device PL 1002 and a Nihon Kohden meb 7102k Neuropack2.

Neurological sequelae were defined when any abnormality persisted after two years of follow-up; they were classified, according to functional capacity evaluated through anamnesis (daily life activities such as feeding, hygiene and school activities) and the neurologic examination, as follows: mild minimal involvement, allowing child independence in daily activities; moderate when causing partial dependence and severe when associated to a quite complete dependence.

The data regarding the numerical variables were summarized through average, medium and deviation patterns; categorical data were summarized and presented in the form of frequency. The adherence to Chi-square statistic was used to test the hypothesis that the patients' distribution was uniform to all ages and also months. The frequencies comparison between the two sexes was accomplished by the binomial test. The tests were considered significant when the $\mathrm{p}$ value obtained was smaller than $5 \%$.

This study was approved by the Institutional Ethics and Review Board.

\section{RESULTS}

Sixty one patients fulfilled the selection criteria, 28 (45.9\%) male and 33 (54.1\%) female, without significant difference between the two sexes (binomial test; $\mathrm{p}=0.609$ ). The age of onset varied from 7 months to 13 years, average 5.9 (pattern deviation=3.45) and there was an uniform distribution of patients along the months

The presence of antecedents at the beginning of the clinical picture was referred in 38 (62\%) patients (Table $1)$; among them, the most frequent was the upper respiratory tract infection (URI) (34.4\%).

Regarding the group of 7 patients with vaccination antecedents, in 3 of them Sabin was concerned, 1 apart from Sabin also received anti-measles, 2 patients received anti-meningococcal and 1 antirabies vaccine.

Time between the antecedent and the beginning of the symptoms varied from 2 to 60 days, 20.7 days average (standard deviation=11.7).

In relation to the clinical presentation, $82 \%(50 / 61)$ developed tetraparesis and 18\% (11/61) crural paraparesis. In 11 patients (18\%) ataxia evidence was found and 3 (4.9\%) of them presented asymmetrical distribution of the deficits. In 4 patients (6.5\%) fever was reported at the beginning of the symptoms.

The clinical course was increased in 95.1\% (58/61) of the patients, however, in 3 of them (4.9\%) the initial symptoms were involvement of the superior members and/or of the cranial nerves.

Table 1. Distribution of antecedents at the beginning of the clinic picture.

\begin{tabular}{lcc}
\hline Antecedents & $\mathrm{n}$ & $\%$ \\
\hline Absent & 23 & 37.7 \\
UTI & 21 & 34.4 \\
Vaccine & 7 & 11.4 \\
Diarrhoea & 3 & 4.9 \\
Hepatitis & 2 & 3.3 \\
Amigdalitis & 1 & 1.6 \\
Fever & 1 & 1.6 \\
Measles & 1 & 1.6 \\
Chickenpox & 1 & 1.6 \\
Contact with agrotoxics & 1 & 1.6 \\
Total & 61 & 100 \\
\hline
\end{tabular}


Table 2. Frequency of cranial nerves involvement.

\begin{tabular}{lcc}
\hline Cranial nerve & $\mathbf{n}$ & $\%$ \\
\hline III & 2 & 3.3 \\
$V I$ & 7 & 11.5 \\
$V I I$ & 27 & 44.3 \\
$I X, X$ & 16 & 26.2 \\
\hline
\end{tabular}

Table 3. Frequency of pain location.

\begin{tabular}{lcc}
\hline Location of pain & $\mathrm{n}$ & $\%$ \\
\hline Inferior limbs & 34 & 55.7 \\
Superior limbs & 6 & 9.8 \\
Lumbar & 7 & 11.5 \\
Cervical & 2 & 3.3 \\
Abdominal & 2 & 3.3 \\
\hline
\end{tabular}

Table 4. Dysautonomic signs and symptoms.

\begin{tabular}{lll}
\hline & $\mathrm{n}$ & $\%$ \\
\hline Blood pressure $\uparrow$ & 14 & 23 \\
Hyperemia & 4 & 6.6 \\
Tachycardia & 3 & 4.9 \\
Hypothermia & 1 & 1.6 \\
Cardiac arrhythmia & 1 & 1.6 \\
\hline
\end{tabular}

Involvement of cranial nerves was present in $34 \mathrm{pa}-$ tients (55.7\%) and Table 2 shows distribution of the affected cranial nerves.

Seventeen patients (27.9\%) presented breathing involvement 9 of them (14.8\%) needing assisted mechanical ventilation.

In 12 patients (19.6\%) there were one or more signs/ symptoms of sphincter disturbs (Figure); pain was present in $62.3 \%$ involving more frequently legs lumbar area, arms and cervical area (Table 3); and 33 patients (57.9\%) have a positive Lasègue sign; dysautonomic signs and symptoms (Table 4) were disclosed in 17 patients (27.9\%); one patient presented an atrio-ventricular block needing a pacemaker device to control it. Sensitive changes were observed in $6.6 \%(4 / 61)$ of patients characterized in three of them as parestesis and pain at extremities.

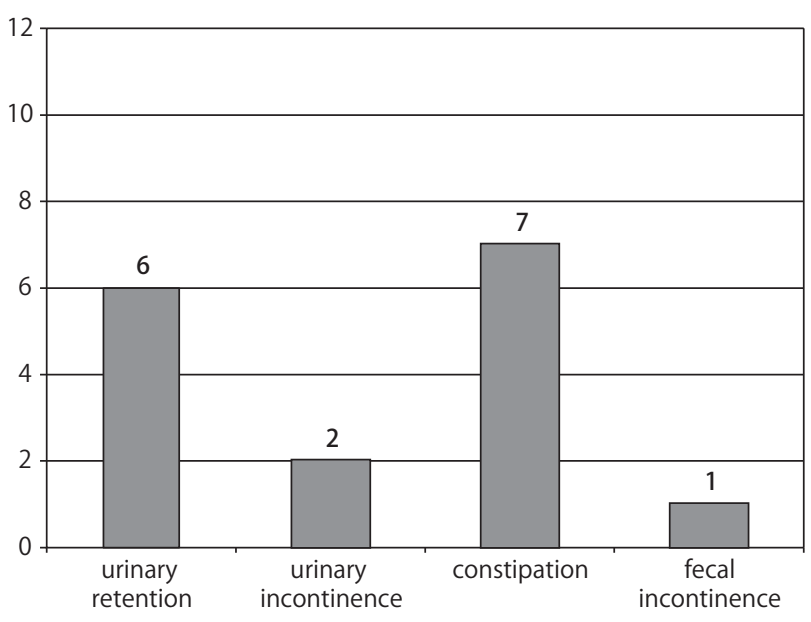

Figure. Distribution of the signs and symptoms of sphincter disturbance.

All patients had decreased or abolished deep reflexes responses at the arms and legs.

Progression phase of the disease in 60 cases varied from 2 to 40 days with 13 days average (standard deviation $=7.9$ ) and plateau phase varied from 0 to 28 days (average 3 days).

Forty-seven of the 50 patients that returned to follow-up evaluation had a complete total recovery (94\%); time to recovery varied from one month to 1 year and 10 months (average 4 months). Three patients presented residual neurologic sequelae: in two of mild and in one of severe degree.

In patients that stopped to walk and were followed up (40/61) functional recovery occurred between 10 months to 1 year (average 33 days). There were no deaths. In Table 5 are disposed the elapsed time of each phase of the disease corresponding to the patients that were followed up.

All patients underwent lumbar puncture in order to analyze cell count and total proteins. Hypercytosis was defined as WBC count $>4$ cells $/ \mathrm{mm}^{3}$ and protein concentration increase was defined as protein concentration $>40$ $\mathrm{mg} / \mathrm{dL}$. All the patients showed increased protein levels and the results are exposed in Table 6.

Only 20 patients performed ENMG that disclosed a demyelination pattern in $75 \%(15 / 20)$, a purely motor axonal in $20 \%(4 / 20)$ and a mixed process, in $5 \%(1 / 20)$.

Table 5. Distribution of the duration time (in days) of the phases of the GBS clinical course.

\begin{tabular}{lcccc}
\hline Phase of the disease & $\mathbf{n}$ & Medium & Minimal time & Maximal time \\
\hline Progression & 60 & 10.5 & 2 & 40 \\
Plateau & 58 & 3 & 0 & 28 \\
Functional recovery & 40 & 33 & 10 & 330 \\
Total recovery & 44 & 120 & 30 & 480 \\
\hline
\end{tabular}


Table 6. Distribution of the patients according CSF cells and total protein concentration.

\begin{tabular}{lccccc}
\hline Cells & $\mathbf{n}$ & $\mathbf{( \% )}$ & Total protein & $\mathbf{n}$ & (\%) \\
\hline Normal & 41 & 67 & Normal & 0 & \\
Mild / Moderate & 20 & 33 & Mild / Moderate & 53 & 87 \\
High / Intense & - & & High & 8 & 13 \\
Total & 61 & 100 & & 61 & 100 \\
\hline
\end{tabular}

Fourteen patients with demyelination pattern and 3 with axonal pattern had a complete recovery; the one with a mixed pattern stayed at the hospital for 3 months, developed respiratory failure and did not return at follow up .

In one patient it was found antecedent of acute polyradiculoneuritis of satisfactory evolution, with a four-year interval.

\section{DISCUSSION}

Our results did not demonstrate significant differences among the incidence of GBS in the masculine and feminine sex, as it has been shown in most of the studies of the western countries, where there is a prevalence of the demyelinizant form ${ }^{1,10}$. However some authors described a discreet prevalence of GBS in males ${ }^{6,11-12}$.

GBS affects patients at any age but is more frequent in adults over 40 years ${ }^{13,14}$. In childhood it usually occurs after the age of 3 years ${ }^{7}$, with reports of incidence peaks ${ }^{1}$; in this series the age varied from 7 months to 13 years with an uniform distribution. The distribution of patients along the year has been uniform, as in most of the countries ${ }^{1}$, except in North of China GBS where it occurs with epidemic characteristics in summer and related to Campilobacter jejuni infection ${ }^{15,16}$.

A previous infection should always be searched particularly when trying to define the presence of some agents more frequently related to GBS.

In $62 \%$ of patients of this series there was a report of a clinical event before the first symptoms of GBS as it is pointed in all series of literature $(60-75 \%)^{6,11,12,14,17}$. Among these events the most frequent was unspecific upper respiratory tract infection.

According to the program of notification of the acute flaccid paralyses of the System of Sanitary Surveillance established in all the states of the federation for the Ministry of Health, the poliovirus research in the stool was accomplished in all the patients with negative results in all of them.

Vaccine antecedent was present in $11.4 \%$ (7/61) of the cases, Sabin vaccine being the most frequent (6.5\%). In the literature there are many case reports, most of them with an insufficient number and just with a mere temporary relationship, pointing to several vaccines as possible triggers of $\mathrm{GBS}^{18}$. An increase of the cases of GBS has been related to mass vaccination programs for Influenza in the United States ${ }^{19,20}$, however, the relationship of GBS with the vaccine of the poliomyelitis remains uncertain and controversial in the literature ${ }^{1,5,18}$.

The time elapsed between the antecedent and the beginning of the symptoms varied from 2 to 60 days, being a little longer in some cases when related to the literature (one to three weeks) $)^{4,7,14}$.

In relation to the clinical presentation, the tetraparetic form was the most frequent involving $82 \%$ of the patients. Three patients (4.9\%) presented asymmetrical distribution of the deficits, usually in the beginning of the picture and that attenuated or disappeared in the development.

The clinical course was increased in $95.1 \%$ (58/61) of the patients, however in $3(4.9 \%)$ the initial symptoms were of involvement of the superior members and/or of the cranial nerves, similar to that related in literature ${ }^{10,21}$, although reports exist, up to 15 to $20 \%$ of increasing forms ${ }^{12,14}$.

The involvement of cranial nerves occurred in 55.7\% of the patients, VII nerve being the most attacked, usually bilateral; that fact has not differed to that found in the literature ${ }^{21}$.

The respiratory involvement (27.9\%), as well as the mechanical ventilation need (14.8\%), were similar to that found in the literature ${ }^{12,22}$.

Pain was present in $62.3 \%$ (38/61), more frequently happening in the inferior members, and it was an important cause of irritability in the smaller children to the point of, at certain moments, make it difficult to accomplish the neurological exam, delaying in some cases the diagnosis. The radicular signs were found in $57.9 \%$ of the patients. Maybe the difference of percentile between the pain complaint is usually related to radicular involvement, and the presence of radicular signs is due to the fact that some patients only arrived at the Service in a later phase, when there was pain reference, however they no longer presented radicular signs.

In $6.6 \%(4 / 61)$ of the patients sensitive alterations were observed: three had paresthesis complaint in the extremities and pain to having the inferior members palpated. As the age group of this casuistry consists of children below 13 years, the subjective complaints are frequently difficult to evaluate.

In the literature, sensitive symptoms are present in 
$50 \%$ of the cases, pain being a prominent symptom, while parestesis and hypoesthesia are present in a minority, and usually in older children ${ }^{7,14}$.

Dysautonomic signs and symptoms were present in $27.9 \%$ of the patients, the most frequent changes being sphincter disturbances and the systemic arterial hypertension. In the literature, the most frequent dysautonomic is the tachycardia ${ }^{23}$, which was not evidenced in this casuistry. That fact maybe is due to a greater need of monitoring of those patients, leading consequently to the identification of that symptom.

The phase of progression of the symptoms was similar to the one observed in the literature (up to four weeks $)^{7,14,21,24}$, except for a patient whose progression phase lasted 40 days.

In the total of 61 patients, only 50 had attendance up until total recovery or for a period of at least 24 months: of those 50 patients, three passed a period without attending the re-evaluation consultations and they returned after a period of 5 to 10 months, for any other complaint, asymptomatic. That lack of follow up is probably due to the fact that GBS has a benign development, in most of the cases. . Total recovery occurred with an average of 120 days, a relatively short time which is observed in the work with children, in the literature ${ }^{25,26}$.

Three patients persisted with sequels after a period of 24 months follow up, which is in agreement with that found in the literature ${ }^{6,7,11,12,27}$.

This series did not register any death, probably for treating of a specific casuistry assisted at a third level hospital, with all conditions to assist critical patients, but maybe it does not reflect the reality of the area.

CSF examination was accomplished in all patients ${ }^{21}$; cell count not protein content exceed 50 cells $/ \mathrm{mL}$ and all showed increased total.

Only 20 patients were submitted to ENMG. In 75\% presented a demyelinizating pattern, $25 \%$ with an axonal pattern and $5 \%$ with a mixed pattern which probably does not reflect an epidemic trait because the exam was accomplished mainly in the most serious patients. Literature shows that $90 \%$ of the patients with GBS in western countries show the demyelizating form ${ }^{10}$. Among the patients with sequels, just one accomplished the ENMG that disclosed a pure motor axonal pattern.

One patient had antecedent of a previous episode of GBS (with a four-year interval). In the first episode this patient was assisted in our service for a period before the beginning of the casuistry. The recurrence possibility is described in the literature ${ }^{7,25}$.

From the statistical point of view, the presence in lighter forms of GBS in the youngest patients can be considered significant, with a larger number of peripatetic forms, however there is the possibility that this difference may be related with the largest difficulty of the neurological exam in smaller children, mainly if there is pain as an important variable.

Another data that presented significant statistical difference, was the time of functional recovery and the time of total recovery, that it was shorter in the youngest patients. The literature describes that possibility, when comparing children's results with the result of adults ${ }^{25,26}$.

Analyzing the patients' clinical characteristics in relation to the time of total recovery, only the variable of the sex showed significant statistical difference, because the male patients showed a longer recovery time. There was no significant statistical difference between the clinical characteristics or the presence of immunomodulator treatment in the studied groups. Studies in the literature that analyze the immunomodulator therapy present beneficial results when applied in the first two weeks of the disease, reducing the time of hospitalization, the time and the need of ventilator support and the extension of the paralysis, not being referred to the correlation with the time of total recovery or the frequency of sequelae ${ }^{24,28}$.

\section{REFERENCES}

1. Dias-Tosta E, Kückelhaus CS. Guillain Barré syndrome in a population less than 15 years old in Brazil. Arq Neuropsiquiatr 2002;60:367-373.

2. Haymaker W, Kernohan JW. The Landry-Guillain-Barré syndrome: a clinicopathologic report of $50 \mathrm{fatal}$ cases and a critique of the literature. Medicine (Baltimore) 1949;28:59-141.

3. Guillain-Barré syndrome Support Group. History of GBS. (Online). Available at http://www.gbs.org.uk/history.html (Sept. 2002).

4. Jones HR Jr. Childhood Guillain-Barré syndrome: clinical presentation, diagnosis, and therapy. J Child Neurol 1996;11:4-12.

5. Ismail EA, Shabani IS, Badawi M, et al. An epidemiologic, clinical, and therapeutic study of childhood Guillain-Barré syndrome in Kuwait: is it related to the oral polio vaccine? J Child Neurol 1998;13:488-492.

6. Winer JB. Guillain Barré syndrome. J Clin Pathol Mol Pathol 2001;54:381-385.

7. Aicardi J (ed). Disease of the nervous system in childhood, acute inflammatory neuropathy, acute polyradiculoneuritis, Guillain-Barré syndrome and related disorders. $2^{\text {th }}$ Ed. London: Mackeith Press 1998;723-727.

8. Sater RA, Rostami A. treatment of Guillain-Barré syndrome with intravenous immunoglobulin. Neurology 1998;51(Suppl 5):S9-S15.

9. Spina-França A (ed). Propedêutica neurológica: temas essenciais. São Paulo: Fundo Editorial Procienx 1969:405-426.

10. Asbury AK. New concepts of Guillain-Barré syndrome. J Child Neurol 2000;15: 183-191.

11. Boucquey D, Sindic CJ, Lamy M, Delmée M, Tomasi JP, Laterre EC. Clinical and serological studies in a series of 45 patients with Guillain-Barré syndrome. J Neurol Sci 1991;104:56-63.

12. Cosi V, Versino M. Guillain-Barré syndrome. J Neurol Sci 2006;27 (Suppl 1):S47-S51.

13. Johnson RT (ed). Viral infections of the nervous system, $2^{\text {th }}$ Ed. Philadelphia: Lippincott-Raven Publ 1998;181-210.

14. Ryan MM. Guillain-Barré syndrome in childhood. J Paediatr Child Health 2005;41:237-241.

15. McKhann GM, Cornblath DR, Griffin JW, et al. Acute motor axonal neuropathy: a frequent cause of acute flaccid paralysis in China.Ann Neurol 1993;33:333-342.

16. Griffin JW, Li CY, Ho TW, et al.Guillain-Barré syndrome in northern China: the spectrum of neuropathological changes in clinically defined cases. Brain 1995;118:577-595.

17. Tellería-Díaz A, Calzada-Sierra. Síndrome de Guillain-Barré. Rev Neurol 2002; 34:966-976.

18. Fonseca LF, Horta MB, Gauzzi LDV (eds). Compêndio de neurologia infantil. Polirradiculoneurite aguda. Síndrome de Guillain-Barré. Belo Horizonte: Medsi 2002;571-575. 
19. Hurwitz ES, Schonberger LB, Nelson DB, Holman RC. Guillain-Barré syndrome and the 1978-1979 influenza vaccine. N Engl J Med 1981;25;304:1557-1561.

20. Piyasirisilp $S$, Hemachudha T Neurological adverse events associated with vaccination. Curr Opin Neurol 2002;15:333-338.

21. Asbury AK, Cornblath DR. Assessment of current diagnostic criteria for Guillain-Barré syndrome. Ann Neurol 1990;27 (Suppl):S21-S24.

22. van der Meché FGA, Schmitz PIM. A randomized trial comparing intravenous immune globulin and plasma exchange in Guillain-Barré syndrome. Dutch Guillain-Barré Study Group. N Engl J Med 1992;326:1123-1129.

23. Asahina M, Kuwabara S, Suzuki A, Hattori T. Autonomic function in demyelinating and axonal subtypes of Guillain-Barré syndrome. Acta Neurol Scand 2002;105:44-50.
24. Abd-Allah SA, Jansen PW, Ashwal S, Perkin RM. Intravenous immunoglobulin as therapy for pediatric Guillain-Barré syndrome. J Child Neurol 1997;12: 376-380.

25. The Italian Guillain-Barré Study Group. The prognosis and main prognostic indicators of Guillain-Barré syndrome: a multicentre prospective study of 297 pacients. Brain 1996:9:2053-2061.

26. Ho TW, Willison HJ, Nachamkin I, et al. Anti-GD1a antibody is associated with axonal but not demyelinating forms of Guillain-Barré syndrome. Ann Neurol 1999;45:168-173.

27. Sladkl JT. Guillain-Barré syndrome in children. J Child Neurol 2004;19:191-200.

28. Barreira AA, Marques W Jr. Revisão crítica sobre os atamentos atuais da síndrome de Guillain-Barré. Rev Bras Neurol 1996;32:161-164. 